\title{
Sequences of digestible lysine for gilts from 60 to 148 days of age
}

\author{
Sequências de lisina digestível para leitoas dos 60 aos 148 dias de idade
}

\author{
Veredino Louzada da Silva Júnior ${ }^{\mathrm{I}}$ Juarez Lopes Donzele ${ }^{\mathrm{I}}$ Rita Flávia Miranda de Oliveira ${ }^{\mathrm{I}}$ \\ Alysson Saraiva $^{\mathrm{I}^{*}}$ Francisco Carlos de Oliveira Silva $^{\text {II }}$ João Luís Kill ${ }^{\mathrm{II}}$
}

\begin{abstract}
The experiment was conducted to evaluate five nutritional plans based on sequences of standardized ileal digestible lysine: 0.90-0.80-0.70, 1.00-0.90-0.80, 1.10-1.00-0.90, $1.20-1.10-1.00$, and 1.30-1.20-1.10\% fed to gilts from 60 to 99 , 129 to 100, and 130 to 148 days of age, respectively. Eighty commercial hybrid gilts, selected for lean gain, with initial weight of $23.46 \pm 0.27 \mathrm{~kg}$ were allotted in a randomized block design, with five treatments, eight replicates, and two pigs per experimental unit. No effect $(P>0.05)$ of the nutritional plans was verified on daily feed intake, daily weight gain and feed conversion. The nutritional plans had no influence $(P>0.05)$ on any of the carcass traits evaluated (carcass yield, meat amount, and meat yield). The nutritional plan of 0.90-0.80-0.70\% standardized ileal digestible lysine fed to gilts from 60 to 99, 100 to 129, and 130 to 148 days of age, respectively, meets the standardized ileal digestible lysine requirements of gilts from 60 to 148 days of age.
\end{abstract}

Key words: amino acid, carcass, performance, pigs, requirement.

\section{RESUMO}

$O$ experimento foi conduzido com o objetivo de avaliar cinco planos de nutrição baseados em sequências de lisina digestível verdadeira: 0,90-0,80-0,70; 1,00-0,90-0,80; 1,10-1,00-0,90; 1,20-1,10-1,00 e 1,30-1,20-1,10\%, fornecidos dos 60 aos 99, dos 100 aos 129 e dos 130 aos 148 dias de idade, respectivamente. Foram utilizadas oitenta leitoas, híbridas comerciais, selecionadas para deposição e carne, com peso inicial

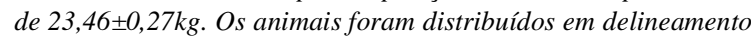
de blocos ao acaso, com cinco tratamentos, oito repetições e dois animais por unidade experimental. Não houve efeito $(P>0,05)$ dos planos nutricionais no consumo de ração diário, no ganho de peso diário e na conversão alimentar. Os planos nutricionais não influenciaram $(P>0,05)$ nenhum dos parâmetros de característica de carcaça avaliados (rendimento de carcaça quente, quantidade de carne e rendimento de carne). O plano nutricional de lisina digestível verdadeira de 0,90-0,80-0,70\% fornecido dos 60 aos 99 , dos 100 aos dos 129 e 130 aos 148 dias de idade, respectivamente, atende às exigências de lisina digestível verdadeira de leitoas dos 60 aos 148 dias de idade.

Palavras-chave: aminoácidos, carcaça, desempenho, exigência, suínos.

\section{INTRODUCTION}

Besides genetic improvement, there are several factors that influence performance and carcass traits of pigs and among then is the amino acid requirement. To obtain high muscle protein deposition rate in pigs genetically improved it is necessary to determine the standardized ileal digestible lysine (SIDL) requirement to ensure the diets allow expression of their maximum genetic potential (YI et al., 2006).

The amino acid lysine has been of greatest interest because of its constancy in body protein and its main metabolic destination for accretion of lean tissue (KESSLER, 1998). Lysine requirements for growing-finishing pigs have been extensively studied (ROSTAGNO et al., 2011) but most of the studies have been conducted considering independent phases.

It has been suggested the importance of working with interdependent nutritional plans in the growing and finishing phases because those has shown to be more efficient in the determination of the nutritional requirements of pigs (KILL et al.,

\footnotetext{
'Universidade Federal de Viçosa (UFV), Av. Peter Henry Rolfs, S/N, Centro, 36570-000, Viçosa, MG, Brasil. E-mail: alysson.saraiva@ufv.br. *Corresponding author.

IEmpresa de Pesquisa Agropecuária de Minas Gerais (EPAMIG), Viçosa, MG, Brasil.

IIIniversidade de Vila Velha (UVV), Vila Velha, ES, Brasil. 
2003; SOUZA, 2009). The advantage of working with nutritional plans instead of independent phases is linked mainly to the metabolic influences that a certain level of a nutrient in the initial phase of growth can exert on its demand in the subsequent phases (MAIN et al., 2008).

Considering the greater potential of gilts for muscle protein accretion (SCHINCKEL \& LANGE, 1996; GRANDHI \& NYACHOTI, 2002) their lysine requirement to maximize gain efficiency is greater compared to barrows. Thus, pigs of different genders will respond differently to nutritional plans based on lysine levels. In this context, this study was conducted to assess nutritional plans based on standardized ileal digestible lysine (SIDL) sequences for gilts from 60 to 148 days of age, considering the differences in SIDL requirement of gilts compared to other genders and at different growth phases.

\section{MATERIAL AND METHODS}

A total of eighty gilts selected for high lean gain with initial weight of $23.34 \pm 0.19 \mathrm{~kg}$ were allotted in a randomized block design with five nutritional plans based on SIDL levels (0.90-0.80$070 ; 1.00-0.90-.080 ; 1.10-1.00-0.90 ; 1.20-1.10-1.00$; $1.30-1.20-1.10 \%$ ), with eight replicates and two pigs per experimental unit (pen). Each SIDL sequence (nutritional plan) was divided into three phases: 60 to 99,100 to 129 , and 130 to 148 days of age. Initial weight was used as the criterion for block formation.

Pigs were housed in pens with semiautomatic feeders, drinkers, and concrete floors. The thermal environment inside the facility was monitored daily using thermometers to measure maximum and minimum temperatures and relative humidity. Thermometers were placed at $50 \mathrm{~cm}$ above the floor. These data were then converted to the black globe humidityindex (BGHI) tocharacterize theenvironment of the pigs, according to BUFFINGTON et al. (1981).

Experimental basal diets for each phase (Table 1) were mainly composed of corn, soybean meal, and supplements of minerals and vitamins to meet the requirements for all nutrients except SIDL (ROSTAGNO et al., 2005). The other experimental diets of each phase were obtained by supplementing L-lysine, DL-methionine, L-threonine, L-tryptophan,

Table 1 - Ingredient composition of basal diets.

\begin{tabular}{|c|c|c|c|}
\hline \multirow{2}{*}{ Item } & \multirow[b]{2}{*}{$60-99$} & \multirow[b]{2}{*}{$100-129$} & \multirow[b]{2}{*}{$130-148$} \\
\hline & & & \\
\hline Corn & 61.590 & 65.890 & 70.530 \\
\hline Soybean meal, $45 \%$ & 31.000 & 26,700 & 22.400 \\
\hline Soybean oil & 2.000 & 2,000 & 1.660 \\
\hline Starter nucleous ${ }^{1}$ & 4.000 & 4.000 & 4.000 \\
\hline Starch & 1.350 & 1.350 & 1.350 \\
\hline Growth promoter ${ }^{2}$ & 0.050 & 0.050 & 0.050 \\
\hline$\beta$-Hydroxytoluene ${ }^{3}$ & 0.010 & 0,010 & 0.010 \\
\hline \multicolumn{4}{|c|}{ - Calculated composition ${ }^{4}$ - } \\
\hline Metabolizable energy, $\mathrm{kcal} / \mathrm{kg}$ & 3250 & 3250 & 3250 \\
\hline Crude protein, $\%$ & 19.00 & 18.00 & 16.00 \\
\hline Digestible lysine, $\%$ & 0.900 & 0.800 & 0.700 \\
\hline Digestible tryptophan, \% & 0.207 & 0.186 & 0.165 \\
\hline Digestible threonine, $\%$ & 0.640 & 0.585 & 0.530 \\
\hline Digestible met + cys, $\%$ & 0.556 & 0.520 & 0.485 \\
\hline Digestible valine, $\%$ & 0.736 & 0.743 & 0.676 \\
\hline Calcium, \% & 0.631 & 0.551 & 0.484 \\
\hline Available phosphorus, $\%$ & 0.332 & 0.282 & 0.248 \\
\hline
\end{tabular}

${ }^{1}$ Provided per kg of product: vitamin A - 93,000UI; vitamin D3 - 24,000UI; vitamin E - 106mg; vitamin K3 - 53mg; thiamin - 13.3mg; pantothenic acid - 173mg; biotin - 0.42mg; pyridoxine - 13.3mg; vitamin B6 $\mathrm{HCl}$ - 8.8mg; folic acid - 520mg; vitamin B12 - $7.000 \mathrm{mg}$; calcium (minimum) - 112g; phosphorus (minimum) - 27g; sodium - 58.5g; iron - 1,820mg; zinc - 2,049mg; copper - 2,126mg; manganese $836 \mathrm{mg}$; iodine - $29.5 \mathrm{mg}$; fluorite (maximum) - 485mg; selenium - $8 \mathrm{mg}$; cobalt - $3.6 \mathrm{mg}$.

${ }^{2}$ Provided per kilogram of complete diet: $20,000 \mathrm{mg}$ of tylosin as tylosin phosphate.

${ }^{3}$ Antioxidant.

${ }^{4}$ Values calculated based on the digestibility coef? cients of AA and ingredients, according to ROSTAGNO et al. (2005).

Ciência Rural, v.45, n.1, jan, 2015. 
and L-valine in place of starch. The ideal amino acid ratios to lysine were maintained as recommended by ROSTAGNO et al. (2005).

Pigs had free access to feed and water throughout the experimental period. Daily feed waste was manually collected and weighed. Animals were weighed at the beginning and at the end of the experimental period to calculate average daily feed intake (ADFI), average daily gain (ADG), and feed conversion (F:G).

At the end of the experimental period (at 148 days of age) all gilts were fasted for 15 hours and transported to a commercial slaughterhouse (Meat Industry Piranga valley, Ponte Nova, Minas Gerais, Brasil). Pigs were electrically stunned followed by exsanguination. Carcasses were individually weighed to obtain hot carcass yield $(\mathrm{kg})$ and then were evaluated for meat amount $(\mathrm{kg})$, meat yield $(\%)$, and backfat thickness using apparatus for carcass classification with Henessay Grading Probe (HGP-4), according to the procedures used by the slaughterhouse.

Performance and carcass traits data were analyzed using the procedures for analysis of variance contained in the Genetic Analysis and Statistic System (SAEG), developed at the Federal University of de Viçosa (UFV, 2000), version 8.0, according to the following statistical model: $\mathrm{Y}_{\mathrm{ijk}}=\mu+$ $\mathrm{B}_{\mathrm{i}}+\mathrm{T}_{\mathrm{j}}+\mathrm{e}_{\mathrm{ijk}}$, in which: $\mathrm{Y}_{\mathrm{ijk}}=$ observed characteristic; $\mu=$ general trait mean; $B_{i}=$ effect of block $i, I=1,2 \ldots$ and $5 ; \mathrm{T}_{\mathrm{j}}=$ effect of level of digestible tryptophan $\mathrm{j} ; \mathrm{j}=$ $1,2 \ldots$ and $5 ; \mathrm{e}_{\mathrm{ijk}}=$ random error associated with each observation. For performance data the experimental unit was represented by the pen and for carcass traits the pig was considered the experimental unit.

\section{RESULTS AND DISCUSION}

In the experimental period from 60 to 99 days of age ( 23.5 up to $57 \mathrm{~kg}$ ) the minimum and maximum temperatures inside the facility were $11.4 \pm 4.0$ and $23.0 \pm 4.4^{\circ} \mathrm{C}$, respectively. Average relative humidity and black globe humidity index (BGHI) were $74.1 \pm 15.3 \%$ and $66.0 \pm 5.1$, respectively. From 100 to 129 and 130 to 148 days of age (57 up to $107 \mathrm{~kg}$ ) the minimum and maximum temperatures inside the facility were $16.6 \pm 3.6$ and $22.6 \pm 4.6^{\circ} \mathrm{C}$, respectively. Average relative humidity and BGHI were $88.9 \pm 10.1 \%$ and $69.3 \pm 3.2$, respectively. The BGHI (BUFFINGTON et al., 1981) is an index used to characterize the thermal environment that incorporates air speed, air temperature, relative humidity, and heat exchange by radiation into a single value.

The range of thermoneutral zone suggested by COFFEY et al. (2000) and PERDOMO (1994) for growing and finishing pigs is between 15 and $24^{\circ} \mathrm{C}$ and 12 and $18^{\circ} \mathrm{C}$, respectively. FERREIRA et al. (2005) reported that a BGHI value of 69.20 provides a thermoneutral environment for 30 - to $60-\mathrm{kg}$ pigs, whereas a BGHI value of 65.6 proposed by SARAIVA et al. (2012) provides a thermoneutral environment for 60 - to $100-\mathrm{kg}$ pigs. These data indicates that pigs used in our experiment were kept most of the time within their thermoneutral zone.

The sequences of standardized ileal digestible lysine (SIDL) had no influence $(\mathrm{P}>0.05)$ on average daily feed intake (ADFI) of pigs (Table 2) from 60 to 148 days of age. This result is consistent with that of ROCHA et al. (2012) who evaluated the same sequences of SIDL used in our experiment

Table 2 - Growth performance and carcass traits of gilts under different nutritional plans from 60 to 148 days of age.

\begin{tabular}{|c|c|c|c|c|c|c|}
\hline \multirow{2}{*}{ Item } & & & & & & \multirow{2}{*}{$\mathrm{CV} \%$} \\
\hline & 1 & 2 & 3 & 4 & 5 & \\
\hline Initial weight, $\mathrm{kg}$ & 23.4 & 23.1 & 23.4 & 23.6 & 23.8 & - \\
\hline Final weight, kg & 104.0 & 107.8 & 105.3 & 108.7 & 108.0 & 4.80 \\
\hline Feed intake, $\mathrm{g} \mathrm{dia}^{-1}$ & 2225 & 2228 & 2190 & 2265 & 2232 & 6.36 \\
\hline Weight gain, $\mathrm{g} \mathrm{dia}^{-1}$ & 916 & 963 & 931 & 967 & 956 & 4,72 \\
\hline Feed conversión & 2.43 & 2.32 & 2.35 & 2.34 & 2.33 & 4.59 \\
\hline \multicolumn{7}{|l|}{ Carcass traits } \\
\hline Carcass yield, $\mathrm{kg}$ & 73.6 & 74.1 & 73.2 & 75.7 & 73.7 & 7.47 \\
\hline Meat amount, kg & 41.7 & 41.6 & 41.2 & 43.5 & 42.4 & 9.18 \\
\hline Meat yield, \% & 56.6 & 56.1 & 56.9 & 57.5 & 57.5 & 3.89 \\
\hline Backfat thickness, mm & 13.4 & 12.5 & 12.8 & 12.6 & 11.6 & 18.69 \\
\hline
\end{tabular}

${ }^{1}$ Nutritional plans: $1=0.90-0.80-0.70,2=1.00-0.90-0.80,3=1.10-1.00-0.90,4=1.20-1.10-1.00$, and $5=1.30-1.20-1.10 \%$ SIDL fed to gilts from 60 to 99,100 to 129 , and 130 to 148 days of age, respectively.

Ciência Rural, v.45, n.1, jan, 2015. 
for gilts from 63 to 153 days of age. Similarly, ALEBRANTE (2012) also verified no effect on ADFI of immunologically castrated pigs fed with SIDL sequences $\quad(0.90-0.80-0.70,1.00-0.90-0.80,1.10$ $1.00-0.90, \quad 1.20-1.10-1.00$, and $1.30-1.20-1.10 \%$ ) from 54 to 154 days of age.

There was no effect $(\mathrm{P}>0.05)$ of SIDL sequences on average daily gain (ADG) of pigs (Table 2), showing that the sequence of 0.90-0.80$0.70 \%$ SIDL meet the requirements of this amino acid for ADG from 60 to 99,100 to 129 , and 130 to 148 days of age, respectively. Investigating the effects of SIDL sequences fed of 20- to $110-\mathrm{kg}$ pigs in which the lowest sequences corresponded to 0.85 $0.75-0.65 \%$ and $0.90-0.80-0.70 \%$ SIDL, SOUZA (2009) and CAMPOS et al. (2010), respectively, also verified no differences on ADG. In more recent studies, ALEBRANTE (2012) e ROCHA et al. (2012) also reported no effect of dietary SIDL sequences (0.9-0.8-0.7 up to 1.2-1.1-1.3\%) on ADG of pigs at the end of the experimental period (54 - 155 days). However, DE LA LLATA et al. (2007) found the sequence 1.04-0.80-0.59\% SIDL resulted in greatest growth response of 27 - to $120-\mathrm{kg}$ gilts. Thus, it is possible to consider that the differences in the levels of lysine studied contributed to the variation on ADG responses verified among researches. Studies to determine the lysine requirements of pigs usually are conducted taking into account specific phases of growth, consistently resulting in values that are greater than those obtained in studies with nutritional plans involving the growth and finishing phases in sequence. Assessing the requirement of SIDL of gilts in each specific phase of growth, MAIN et al. (2008) and SHELTON et al. (2011) verified that ADG was influenced by dietary SIDL content with best performance obtained at 1.02, 1.01, and $0.72 \%$ SIDL (MAIN et al., 2008) and 1.03, 0.90, and 0.89\% SIDL (SHELTON et al., 2011) from 35 to 60, 60 to 80 , and 80 to $110 \mathrm{~kg}$, respectively. With these results, one can infer the methodology used to determine the SIDL requirement of pigs by phase of growth or by sequential nutritional plans result in different requirements.

In this sense, taking as reference the study of SOUZA (2009), the author found that even though the greatest response of ADG in the first phase (17.5 to $44.5 \mathrm{~kg}$ ) was obtained at $1.15 \%$ SIDL, when analyzing the total period (17.5 to $107 \mathrm{~kg}$ ) there was no change in ADG although the sequence with the lowest level of SIDL evaluated corresponded to $0.85 \%$ SIDL for first phase.

In a study with barrows and gilts from 30 to $110 \mathrm{~kg}$, CAMPOS et al. (2010) confirmed the results found by SOUZA (2009) where the SIDL requirement for ADG during growth was greater when data were analyzed by specific phases compared to the analysis done considering the entire period (1.10x0.90\%). According to CHIBA (1995), the use of suboptimal lysine levels $\left(0.423 \times 0.765 \mathrm{~g} \mathrm{MJ}^{-1} \mathrm{DE}\right)$ in diets for pigs in the growing phase $(22.4$ to $50.5 \mathrm{~kg})$, did not negatively affect the growth rate of pigs in a total period (22.4 to $107.6 \mathrm{~kg})$.

There was no effect $(\mathrm{P}>0.05)$ of SIDL sequences on feed conversion $(\mathrm{F}: \mathrm{G})$ which makes possible to infer that $0.90,0.80$, and $0.70 \%$ fed from 23 to 57,57 to 87 , and 87 to $107 \mathrm{~kg}$ meet the requirements of pigs for improved growth efficiency. Consistent with this result, SOUZA (2009) and CAMPOS et al. (2010) also observed no variation in the efficiency of feed utilization for weight gain of barrows and gilts from 20 to $120 \mathrm{~kg}$ when assessing different nutritional plans based on SIDL sequences consistent with the sequences used in the present study. Although DE LA LLATA et al. (2007) in studies conducted with barrows and gilts from 27 to $120 \mathrm{~kg}$ found the SIDL influenced F: Gof pigs, the levels which resulted in best responses were similar to those obtained in this study. Thus, similarly as verified for ADG the studies of MAIN et al. (2008) and SHELTON et al. (2011) with gilts considering each particular phase of growth, between 30 and $120 \mathrm{~kg}$, revealed that the levels of SIDL influenced F:G in each phase evaluated and the levels which resulted in greatest responses were above those verified by the authors when analysis were done considering the total period.

Since the values of $A D G$ and $F: G$ of pigs observed in the studies of MAIN et al. (2008) (906g X 2.12) and SHELTON et al. (2011) (918gx2.10) were similar to those obtained by FIELDS et al. (2010) (923g and 2.08), the differences in results among the studies cannot be associated with possible genetic differences among pigs concerning to their potential and efficiency of growth.

The sequences of SIDL had no influence $(\mathrm{P}>0.05)$ on carcass yield (Table 2). Similar results were obtained by SOUZA FILHO (2000) and KILL et al. (2003) assessing the influence of nutrition plans based on SIDL sequences on carcass traits of 30 to 130 and 65- to $105 \mathrm{~kg}$ pigs, respectively. Lack of variation on carcass yield of barrows and gilts from 20 to $120 \mathrm{~kg}$ was also reposted by DE LA LLATA et al. (2007). Based on this consistent response pattern one can infer that carcass yield is not an appropriate parameter to assess the lysine requirement of pigs.

There was no effect $(\mathrm{P}>0.05)$ of SIDL sequences on meat amount $(\mathrm{kg})$ or meat yield $(\%)$, 
leading to the conclusion that the sequence with the lowest SIDL levels assessed allowed the pigs to express their full potential for meat deposition. Similarly, studying SIDL for 20 to $120 \mathrm{~kg}$ barrows and gilts SOUZA (2009) observed no differences in loin depth or meat percentage, and CAMPOS et al. (2010) found no variation in the rate of protein accretion in the carcass of pigs throughout the experimental period.

Evaluating the effects of SIDL levels on performance and carcass traits of finishing gilts, KILL et al. (2003) and MAIN et al. (2008) also found no effect on carcass meat percentage. However, in a study conducted by DE LA LLATA et al. (2007) with 27 to $120 \mathrm{~kg}$ pigs the authors verified that loin eye area and meat percentage in the carcass were influenced by the dietary levels of lysine. Considering that among the studies mentioned above, in which lysine requirements were assessed considering the whole phase (growing to finishing), DE LA LLATA et al. (2007) was the one assessing SIDL sequences at levels below the others, it can be concluded that this was a factor that may justify the difference seen among results. Investigating the effect of lysine levels $(0.70,0.95,1.20$, and $1.45 \%)$ on protein metabolism of growing pigs, REN et al. (2007) observed that the increase in body protein deposition occurred only between the two lower levels of lysine. Furthermore, according to the authors, the increased lysine levels from 0.95 to $1.45 \%$ did not affect the synthesis and degradation of protein, hence pigs from the different treatments presented in a similar fashion maintaining unchangedbody protein deposition, which is consistent with the results of DE LA LLATA et al. (2007).

Based on the reports of SCHINCKEL et al. (2008) and ARTHUR et al. (2009) that increasing protein deposition would result in improvement $F: G$ of pigs, one can infer the data of meat amount and meat percentage obtained in this study are consistent with the data of performance.

The backfat thickness at $\mathrm{P}_{2}(\mathrm{BF})$ did not differ $(\mathrm{P}>0.05)$ among the SIDL sequences. In studies conducted with growing-finishing barrows and gilts to assess nutritional plans based on SIDL sequences, SOUZA (2009) and CAMPOS et al. (2010) found no effect on BF. Lack of variation on BF of 100 to $120 \mathrm{~kg}$ gilts, was also reported by MAIN et al. (2008). On the other hand, KILL et al. (2003) observed that BF of gilts slaughtered at $105 \mathrm{~kg}$ was affected by nutritional plans consisting of SIDL sequences.

The difference in results regarding to the influence of lysine on BF among studies may be explained in part by genetic differences of pigs used, taking into account that gilts of regular, medium, and high performance respond in a different way to lysine supplementation. According to WAGNER etal.(1999), for pigs slaughtered at $100 \mathrm{~kg}$ there is a BF variation up to $40 \%$ among the genetics available on the market. Given the negative correlation between protein accretion and backfat thickness of pigs (FRIESEN et al., 1994), the fact that meat amount and meat yield were not affected by the SIDL sequences in this study justifies the results of BF observed.

\section{CONCLUSION}

The nutritional plan $0.90-0.80-0.70 \%$ standardized ileal digestible lysine provided from 60 to 99,100 to 129 , and 130 to 148 days of age, respectively, meets the digestible lysine requirements of growing-finishing gilts from 60 to 148 days of age.

\section{ETHICS COMMITTEE AND BIOSAFETY}

Protocol n.4/2013

\section{REFERENCES}

ALEBRANTE, L. Níveis e planos nutricionais de lisina digestível para suínos machos do crescimento à terminação. 2012. 54f. Tese (Doutorado em Zootecnia) - Curso de Pós-graduação em Zootecnia, Universidade Federal de Viçosa, MG.

ARTHUR, P.F. etal. Measures of growth and feed efficiency and their relationships with body composition and carcass traits of growing pigs. Animal Production Science, v.49, p.1105-1112, 2009.

BUFFINGTON, D.E. et al. Black-Globe-Humidity Index (BGHI) as comfort equations for dairy cows. Transactions of the ASAE, v.24, p.711-714, 1981.

CAMPOS, P.F. et al. Digestible lysine levels for gilts and barrows with high genetic potential for lean meat gain from 30 to $110 \mathrm{~kg}$. In: EAAP INTERNATIONAL SYMPOSIUM ON ENERGY AND PROTEIN METABOLISM AND NUTRITION, 3., 2010, Parma, Italy. Proceedings... Wageningen, NL: Wageningen Academic Publishers, 2010. p.633-634.

CHIBA, L.I. Effects of nutritional history on the subsequent and overall growth performance and carcass traits of pigs. Livestock Production Science, v.41, p.151-161, 1995. Available from: <http://dx.doi.org/10.1016/0301-6226(94)00050-H>. Accessed: Apr. 27, 2011. doi: 10.1016/0301-6226(94)00050-H.

COFFEY, R.D. et al. Feeding growing-finishing pigs to maximize lean grow rate. Kentucky: Kentucky Cooperative Extension Service, 2000. Available from: <http://www.animalgenome.org/ edu/PIH/prod_grow_finish.pdf>. Online. Accessed:Apr. 27. 2011.

DE LA LLATA, M. et al. Effects of increasing lysine to calorie ratio and added fat for growing-finishing pigs reared in a commercial environment: I. Growth performance and carcass characteristics. Professional Animal Scientist, v.23, p.417-428, 2007. Available from: <http://pas.fass.org/content/23/4/417.full. pdf+html>. Accessed: Apr. 30, 2011.

Ciência Rural, v.45, n.1, jan, 2015. 
FERREIRA, R.A. et al. Redução do nível de proteína bruta e suplementação de aminoácidos em rações para supinos machos castrados mantidos em ambiente termoneutro dos $30 \mathrm{a} 0 \mathrm{~s} 60 \mathrm{~kg}$. Revista Brasileira de Zootecnia, v.34, p.548-556, 2005. Available from: 〈http://www.revista.sbz.org.br>. Accessed: Nov. 25, 2013.

FIELDS, A.P. et al. Characterization of growth parameters needed as inputs for pig growth models. Journal of Animal Science, v.74, p.2021-2036, 1996. Available from: <http:// www.journalofanimalscience.org/content/74/8/2021>. Accessed: Mar. 26, 2013.

FRIESEN, K.G. et al. Influence of dietary lysine on growth and carcass composition of high-lean-growth gilts fed from 34 to 72 kilograms. Journal of Animal Science, v.72, 1761-1770, 1994. Available from: <http://www.journalofanimalscience.org/ content/72/7/1761>. Accessed: Nov. 25, 2011.

GRANDHI, R.R.; NYACHOTI, C.M. Effect of true ileal digestible dietary methionine to lysine ratios on growth performance and carcass merit of boars, gilts and barrows selected for low backfat. Canadian Journal of Animal Science, v.82, p.399-407, 2002.

KESSLER, A.M. Exigências nutricionais para máximo rendimento de carne e suíno. In: SIMPÓSIO SOBRE RENDIMENTO E QUALIDADE DE CARNE SUÍNA, 1998, Concórdia-SC. Anais... Concórdia: EMBRAPA-CNPSA, 1998. p.18-25.

KILL, J.L. et al. Planos de nutrição para leitoas com alto potencial genético para deposição de carne magra dos 65 aos 105kg. Revista Brasileira Zootecnia, v.32, p.1330-1338, 2003. Available from: <http://www.revista.sbz.org.br/artigo/visualizar. php?artigo=3478>. Accessed: Nov. 25, 2011. doi: 10.1590/ S1516-35982003000600007.

MAIN, R.G. et al. Determining an optimum lysine:calorie ratio for barrows and gilts in a commercial finishing facility. Journal of Animal Science, v.86, p.2190-2207, 2008. Available from: <http://www.journalofanimalscience.org/content/86/9/2190>. Accessed: Mar. 26, 2013. doi:10.2527/jas.2007-0408.

PERDOMO, C.C. Conforto ambiental e produtividade de suínos. In: SIMPÓSIO LATINO AMERICANO DE NUTRIÇÃO DE SUÍNOS, 1994, São Paulo, SP. Anais... São Paulo, SP: Colégio Brasileiro de Nutrição Animal, 1994. p.19-26.

REN, J.B. et al. Influence of dietary lysine level on whole-body protein turnover, plasma IGF-I, GH and insulin concentration in growing pigs. Livestock Science, v.110, p.126-132, 2007. Available from: <http://www.livestockscience.com/article/ S1871-1413(06)00394-5/fulltext>. Accessed: Mar. 26, 2013. doi:10.1016/j.livsci.2006.10.009.

ROCHA, G.C. et al. Sequence of apparent ileal digestible lysine for growing-finishing gilts. In: America Society of Animal Science, 2012, Phoenix. America Society of Animal Science, 2012.
ROSTAGNO, H.S. et al. Tabelas brasileiras para aves e suínos: composição de alimentos e exigências nutricionais de aves e suínos. 2. ed. Viçosa: UFV, 2005. 186p.

SARAIVA, A.; DONZELE, J.L.; OLIVEIRA, R.F.M. et al. Phosphorus requirements for 60- to 100-kg selected for high lean deposition under diferente termal environments. Journal of Animal Science, v.90, p.1499-1505, 2012. Accessed: Mar. 26, 2013.

SCHINCKEL, A.P. et al. Growth of protein, moisture, lipid, and ash of two genetic lines of barrows and gilts from twenty to one hundred twenty-five kilograms of body weight. Journal of Animal Science, v.86, p.460-471, 2008. Available from: <http://www. journalofanimalscience.org/content/86/2/460.full>. Accessed: Mar. 28, 2013. doi:10.2527/jas.2007-0625.

SCHINCKEL, A.P.; DE LANGE, C.F.M. Characterization of grow th parameters needed as inputs for pig growth models. Journal of Animal Science, v.74, p.2021-2036, 1996. Available from: <http://www.journalofanimalscience.org/content/74/8/2021>. Accessed: Mar. 26, 2013.

SHELTON, N.W. et al. Effects of increasing dietary standardized ileal digestible lysine for gilts grown in a commercial finishing environment. Journal of Animal Science, v.89, p.3587-3595, 2011. Available from: <http://www.journalofanimalscience.org/ content/89/11/3587.full>. doi: 10.2527/jas.2010-3030.

SOUZA FILHO, G.A. et al. Efeito de planos de nutrição e de genótipos sobre características físicas de carcaça de suínos. Ciência e Agrotecnologia, v.24, p.1060-1067, 2000.

SOUZA, L.P.O. Níveis de lisina digestível e planos de nutrição baseados em níveis de lisina digestível para suínos machos castrados e fêmeas, dos 18 aos 107 kg. 2009. 54p. Dissertação (Mestrado em Zootecnia) - Curso de Pós-graduação em Zootecnia, Universidade Federal de Minas Gerais, MG.

UNIVERSIDADE FEDERAL DE VIÇOSA (UFV). SAEG Sistemas de análises estatísticas e genéticas. Viçosa, MG, 2000. (Versão 8.0).

WAGNER, J.R. et al. Analysis of body composition changes of swine during growth and development. Journal of Animal Science, v.77, p.1442-1466, 1999. Available from: <http://www.journalofanimalscience. org/content/77/6/1442>. Accessed: Mar. 26, 2013.

YI, G.F. et al. Estimation of the true ileal digestible lysine and sulfur amino acid requirement and comparison of the bioefficacy of 2-hydroxy-4-(methylthio)butanoic acid and DL -methionine in eleven- to twenty-six-kilogram nursery pigs. Journal of Animal Science, v.84, p.1709-1721, 2006. Available from: <http://www. journalofanimalscience.org/content/84/7/1709.full>. Accessed: Mar. 26, 2013. doi: 10.2527/jas.2005-465. 